\title{
Solution structure of the pseudo-5' splice site of a retroviral splicing suppressor
}

\author{
JAVIER CABELLO-VILLEGAS, ${ }^{1}$ KEITH E. GILES, ${ }^{2}$ ANA MARIA SOTO, ${ }^{3}$ PING YU, ${ }^{1}$ ANNIE MOUGIN, ${ }^{4}$ \\ KAREN L. BEEMON, ${ }^{2}$ and YUN-XING WANG ${ }^{1}$ \\ 1 Protein-Nucleic Acid Interaction Section, Structural Biophysics Laboratory, CCR, NCI-Frederick, NIH, Frederick, Maryland 21702, USA \\ ${ }^{2}$ Department of Biology and ${ }^{3}$ Department of Chemistry, Johns Hopkins University, Baltimore, Maryland 21218, USA \\ ${ }^{4}$ Laboratoire de Maturation des ARN et Enzymologie Moléculaire, UMR 7567 CNRS-UHP Nancy I, Vandoeuvre-Les-Nancy 54506, France
}

\begin{abstract}
Control of Rous sarcoma virus RNA splicing depends in part on the interaction of U1 and U11 snRNPs with an intronic RNA element called the negative regulator of splicing (NRS). A 23mer RNA hairpin (NRS23) of the NRS directly binds U1 and U11 snRNPs. Mutations that disrupt base-pairing between the loop of NRS23 and U1 snRNA abolish its negative control of splicing. We have determined the solution structure of NRS23 using NOEs, torsion angles, and residual dipolar couplings that were extracted from multidimensional heteronuclear NMR spectra. Our structure showed that the 6-bp stem of NRS23 adopts a nearly A-form duplex conformation. The loop, which consists of 11 residues according to secondary structure probing, was in a closed conformation. U913, the first residue in the loop, was bulged out or dynamic, and loop residues G914-C923, G915-U922, and U916-A921 were base-paired. The remaining UUGU tetraloop sequence did not adopt a stable structure and appears flexible in solution. This tetraloop differs from the well-known classes of tetraloops (GNRA, CUYG, UNCG) in terms of its stability, structure, and function. Deletion of the bulged U913, which is not complementary to U1 snRNA, increased the melting temperature of the RNA hairpin. This hyperstable hairpin exhibited a significant decrease in binding to U1 snRNP. Thus, the structure of the NRS RNA, as well as its sequence, is important for interaction with U1 snRNP and for splicing suppression.
\end{abstract}

Keywords: U1 snRNP binding site; NRS; NMR structure; UUGU tetraloop; U bulge

\section{INTRODUCTION}

The spliceosome is a large and highly dynamic RNA-protein machine that is assembled in a stepwise manner (for review, see Burge et al. 1999). An early step in splicing is the recognition of the $5^{\prime}$ splice site, which involves binding of U1 snRNP (Mount et al. 1983; Bindereif and Green 1987; Michaud and Reed 1991) through sequence-specific RNARNA and protein-RNA interactions with the splice site (Du and Rosbash 2002; Lund and Kjems 2002). However, the binding of U1 snRNP to a pre-mRNA is not sufficient to define a $5^{\prime}$ splice site (Eperon et al. 1993; Gontarek et al. 1993; Hastings et al. 2001). According to the exon definition model, both splice sites of an internal exon must be recognized together by interactions that occur across the exon

Reprint requests to: Karen L. Beemon, Department of Biology, Johns Hopkins University, Baltimore, MD 21218, USA; e-mail: KLB@jhu.edu; fax: (410) 516-7292; or Yun-Xing Wang, Protein-Nucleic Acid Interaction Section, Structural Biophysics Laboratory, CCR, NCI-Frederick, NIH, Frederick, MD 21702, USA; email: wangyu@ncifcrf.gov; fax: (301) 8466231.

Article and publication are at http://www.rnajournal.org/cgi/doi/ 10.1261/rna.7020804.
(Robberson et al. 1990). In addition to this major type of intron in which U2 snRNP binds the branch site, a minor class of introns features U11 snRNP binding to the 5' splice site and U12 snRNP binding to the branch-point sequence (Kolossova and Padgett 1997; Burge et al. 1999). RNA structure has previously been shown to play a role in splice site selection because the placement of an exon within a hairpin loop promotes its skipping (Solnick 1985). Similarly, placement of a splice site within a helical stem can prevent its recognition (Jacquenet et al. 2001; Honig et al. 2002).

Rous sarcoma virus (RSV) is a simple avian retrovirus that generates both unspliced and two singly spliced mRNAs from a single primary transcript through alternative splicing (for review, see Rabson and Graves 1997). The maintenance of the unspliced RNA is aided by a cis-acting element, spanning RSV nucleotides 703-930, termed the negative regulator of splicing (NRS; Arrigo and Beemon 1988; McNally et al. 1991; McNally and Beemon 1992). The NRS is a bipartite element that suppresses the use of the upstream viral $5^{\prime}$ splice site. It has a $5^{\prime}$ region that can function as a splicing enhancer in heterologous contexts 
and has been shown to bind SR proteins and hnRNP $\mathrm{H}$ (McNally and McNally 1998; Fogel and McNally 2000). The $3^{\prime}$ region of the NRS resembles overlapping major and minor $5^{\prime}$ splice site sequences and is capable of binding both U1 and U11 snRNPs (Gontarek et al. 1993; Hibbert et al. 1999; McNally and McNally 1999). Mutations in the U1 snRNP-binding region result in increased viral $s r c$ mRNA splicing (O'Sullivan et al. 2002). When U1 snRNP binds the NRS, it competes with the authentic viral $5^{\prime}$ splice site for interaction with the downstream $3^{\prime}$ splice sites and suppresses splicing by forming a nonproductive splicing complex (Cook and McNally 1999; Hibbert et al. 1999; O'Sullivan et al. 2002). In contrast, when U11 snRNP binds the NRS, it is hypothesized to block binding of U1 snRNP to the overlapping sequence and to allow viral splicing to occur (Hibbert et al. 1999; McNally and McNally 1999). In this way, an appropriate balance between unspliced and spliced viral RNAs is maintained. Although the viral NRS sequence is not spliced, a single U-to-A substitution at nonconsensus position $913(-2), 917(+3)$, or $918(+4)$ converts it into an efficient splice site (Paca et al. 2001).

To aid in determining why the NRS sequence functions as a splicing suppressor rather than as a splice site, we determined the structure of NRS23, a 23-nt RNA that interacts with U1 and U11 snRNPs. Chemical and enzymatic probing of the full-length NRS RNA secondary structure showed that NRS23 RNA formed a hairpin. The 3D structure results, obtained by NMR, indicate that NRS23 is a stem-loop structure, containing $9 \mathrm{bp}$, a nonstructured UUGU tetraloop, and a bulged or dynamic $U$ at position -2 of the major $5^{\prime}$ splice-site-like sequence. Five of the nucleotides that are poised to base-pair with U1 snRNA are involved in intramolecular base-pairing in the absence of U1. Thus, the NRS23 helix must be at least partially unwound before U1 snRNA can base-pair with it. The bulged U913 appears to prevent NRS23 from forming a continuous Aform helix. We deleted U913 from NRS23 and observed a dramatic increase in the stability of the remaining RNA structure, coupled with a decrease in the affinity of U1 snRNP for the NRS23 RNA. This result suggests that helix destabilization is necessary for binding of U1 snRNP to the NRS. We conclude that intramolecular interactions within NRS23 must be destabilized before intermolecular interactions with $\mathrm{U} 1$ can be formed. The partial occlusion of the U1 binding site by intramolecular base-pairing may regulate RSV RNA splicing.

\section{RESULTS}

\section{Secondary structure determination reveals NRS23 forms a hairpin structure}

Nuclease probing with RNases T2 and V1 and chemical modification with lead was used to determine the secondary structure of the full-length NRS RNA (data not shown).
When experiments were carried out in the presence of 20 $\mathrm{mM} \mathrm{Mg}^{+2}$, a hairpin structure was clearly observed at the $3^{\prime}$ end of the NRS, containing nucleotides 907 to 929 (Fig. 1A). This hairpin had a 6-bp stem and an 11-nt loop and was termed NRS23. Centered within this hairpin, a 15-residue internal sequence resembles overlapping major and minor (U2- and U12-dependent) $5^{\prime}$ splice site sequences and is capable of binding either U1 or U11 snRNP (Gontarek et al. 1993; Hibbert et al. 1999; McNally and McNally 1999). This region has a $5 / 8$ identity to the consensus sequence for a major $5^{\prime}$ splice site (shown in yellow in Fig. 1A; Mount et al. 1983). Further, U1 snRNA has been shown, by NRS mutation and compensatory U1 mutation experiments (Hibbert et al. 1999), to interact with residues within this loop, as shown in Figure 1B. U1 snRNA nucleotides 1-9 are complementary to the NRS loop sequence, with the exception of mismatches at nucleotides 5 and 6 . The loop and the flanking stem also contain the minor 5' splice site consensus sequence (GUAUCCUU; Kolossova and Padgett 1997; Burge et al. 1999), and U11 snRNA nucleotides 4 through 18 are complementary to sequences in the loop and flanking it (Fig. 1C). A portion of these same snRNA sequences bind to authentic 5' splice sites (Mount et al. 1983; Kolossova and Padgett 1997; Burge et al. 1999).

\section{NMR analysis and solution structure of NRS23}

We have determined solution structures for the NRS 23 RNA, using NOEs, torsion angles, hydrogen bond restraints, the DELPHIC database (Clore and Kuszewski

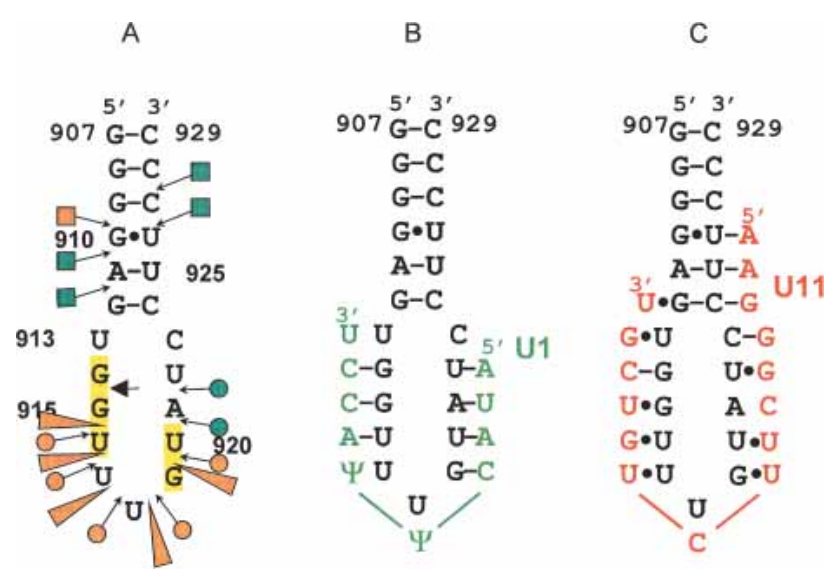

FIGURE 1. RSV NRS23 RNA is complementary to both U1 and U11 snRNAs. (A) The NRS23 secondary structure determined by nuclease probing and chemical modification. The pseudo $5^{\prime}$ splice site is indicated by a large arrow. The sequence highlighted in yellow is identical to the $5^{\prime}$ splice site consensus. Results of the chemical and enzymatic probing are indicated as follows: RNase V1 or T2 cleavages are indicated by small arrows linked to squares or circles, respectively, and lead cleavages by triangles. Colors indicate cleavage yields (green and orange for weak and medium). (B) NRS23 is shown interacting with complementary sequences from U1 snRNA (residues 1 to 10). (C) NRS23 can also base-pair with U11 snRNA (residues 4 to 18). 
2003), and residual dipolar couplings (RDCs; Fig. 2; Table 1). The NRS23 solution structures comprise a stem, consisting of G907-G912 on one side and C924-C929 on the complementary side, as predicted by secondary structure analysis (Fig. 1A). The stem is followed by a bulged U913 and three in-loop base pairs, G914-C923, G915-U922, and U916-A921, and a less defined UUGU tetraloop. The U916-A921 base pair is unstable. The average RMSD of heavy atoms of the stem (residues 907-915/922-929, excluding the bulged U913) of the 15 lowest-energy structures relative to those of the minimized average structure is $\sim 0.61$ $\AA$ (Table 1). In the average minimized structure, the bulge caused an $\sim 13^{\circ}$ tilt between bases 912 and 914 in an otherwise continuous A-form helix (Walsh et al. 2004). This tilt was $\sim 27^{\circ}$ when RDCs were not included in the refinement. Based on this 3D structure, a new secondary structure scheme, with some detected NOE connectivity, is drawn in Figure 3 (for clarity, we omitted the first $3 \mathrm{bp}$ in the stem from this figure). The experimental data to support the new base-pairing in the 11-residue loop are discussed in detail later.

NRS23 contains a bulged or dynamic U913 that disrupts an otherwise continuous helix from the stem to the loop (Fig. 2). This bulge was predicted by the program Mfold (Mathews et al. 1999; Zuker 2003). Point mutations at this position affect NRS activity (Paca et al. 2001). The absence of sequential NOEs and of imino resonance for U913 indicates that this residue is either dynamic or bulged out (Fig. 2B). The NOEs, COSY cross-peaks, and ${ }^{13} \mathrm{C}$ chemical shifts indicate that ribose puckers flanking residues 912 to 914 have some $\mathrm{C}^{\prime}$ ' endo character. The bulged U913 position is not well defined in the final ensemble of structures. The back-calculated RDCs, based on the non-RDC refined structure, have a large RMSD compared with the experi-
TABLE 1. Restraints and statistics of NRS23 NMR structure

\begin{tabular}{|c|c|c|c|}
\hline \multicolumn{4}{|l|}{ Restraints } \\
\hline NOE distance & \multicolumn{3}{|c|}{377} \\
\hline Torsion angle & \multicolumn{3}{|c|}{46} \\
\hline Base-pairing & \multicolumn{3}{|c|}{63} \\
\hline RDC $^{a}$ (stem) & \multicolumn{3}{|c|}{77} \\
\hline \multirow[t]{3}{*}{ RDC $^{\mathrm{b}}$ (nonstem) } & \multicolumn{3}{|c|}{40} \\
\hline & No RDC & No RDC & RDC \\
\hline & No DELPHIC & DELPHIC & DELPHIC \\
\hline \multicolumn{4}{|l|}{ Energy (kcal/mole) } \\
\hline Bond & 11.49 & 25.37 & 15.91 \\
\hline Angle & 169.8 & 224.12 & 235.1 \\
\hline Improper & 4.2 & 4.23 & 4.7 \\
\hline Van der Waals & 17.8 & 84.55 & 120.9 \\
\hline NOE & 14.5 & 29.38 & 50.1 \\
\hline Dihedral & 1.8 & 17.56 & 17.5 \\
\hline Planarity & 3.3 & 2.09 & 1.6 \\
\hline $\mathrm{RDC}$ & 0 & 0 & 339.2 \\
\hline Orientation $^{c}$ & 0 & -596.09 & -583.8 \\
\hline \multicolumn{4}{|l|}{ Violation } \\
\hline NOE & 0.07 & 0.11 & 0.4 \\
\hline Torsion angle & 0.27 & 0.31 & 3 \\
\hline \multicolumn{4}{|l|}{$\operatorname{RMSD}^{\mathrm{d}}(\AA)$} \\
\hline Stem $^{\mathrm{e}}$ & 1.99 & & 0.53 \\
\hline Loop & 1.52 & & $-^{f}$ \\
\hline \multicolumn{4}{|c|}{$\begin{array}{l}\text { a Only RDCs of the stem region were used in the final structure } \\
\text { calculation. } \\
\text { b } R \text { DCs of the nonstem region were used in two alignment tensor } \\
\text { calculations but not used in the final structure calculation. } \\
\text { 'The potential energy for DELPHIC calculation (Clore and Kus- } \\
\text { zewski 2003). } \\
\text { d Root-mean-square-deviation of heavy atoms relative to those of } \\
\text { the minimized average structure of the NRS23 NMR structure. } \\
\text { eStem is defined as six base pairs (residues } 907-912 / 924-929 \text { and } \\
914-916 / 921-923 \text { ), excluding U913 bulge. } \\
\text { In the final structure calculation, the RDCs were not used to refine } \\
\text { the loop structure because of its dynamic behavior (see the discus- } \\
\text { sion in the text). }\end{array}$} \\
\hline
\end{tabular}

A

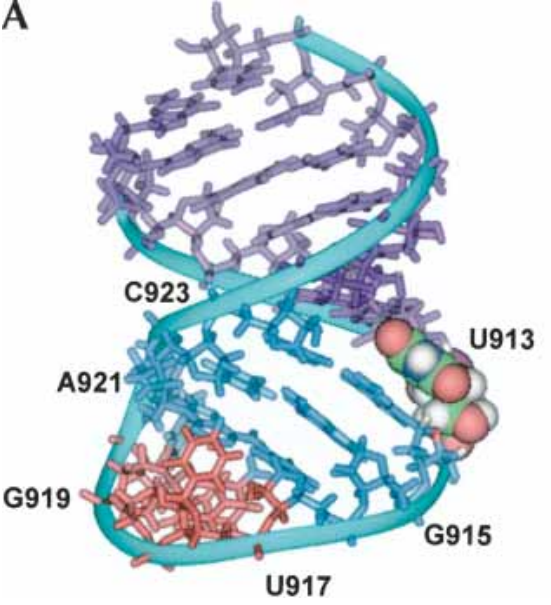

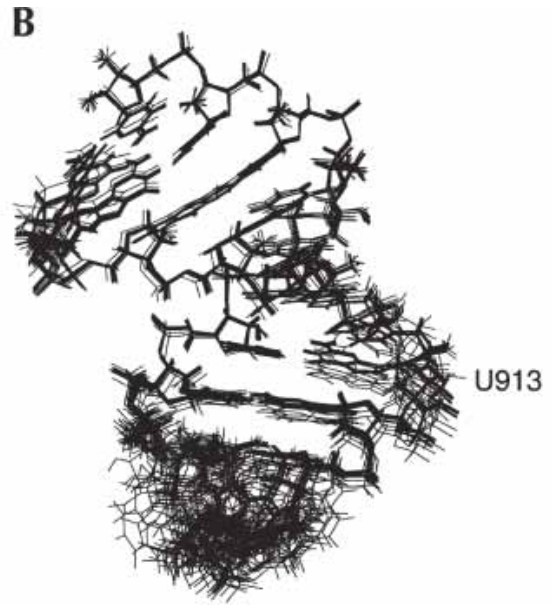

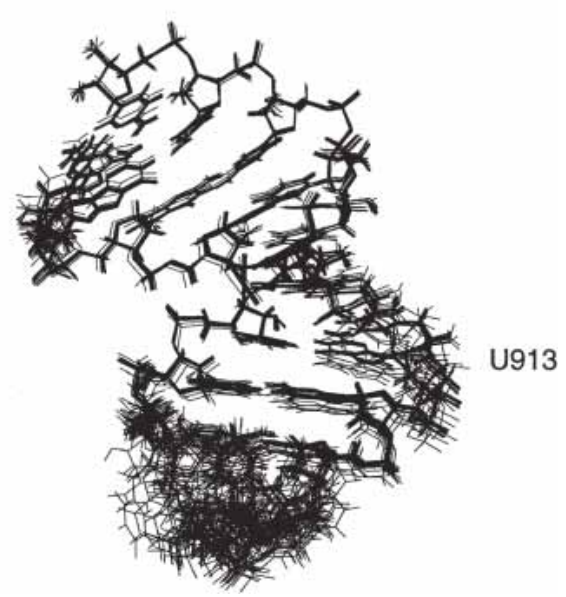

FIGURE 2. Solution structures of NRS23. The solid model drawing of the NRS23 RNA structure $(A)$ and the stereo plot of the 15 lowest-energy structures calculated with RDCs $(B)$. The structures are aligned with the stem residues. The structures refined with RDCs are more extended than those refined without RDCs. The tilt of the bases flanking U913 is $\sim 13^{\circ}$. Color code in A: purple, stem region before the U913 bulge; blue, 3 bp in loop; light red, the UUGU tetraloop. For clarity, the bulged U913 is drawn as a space-filling model. 


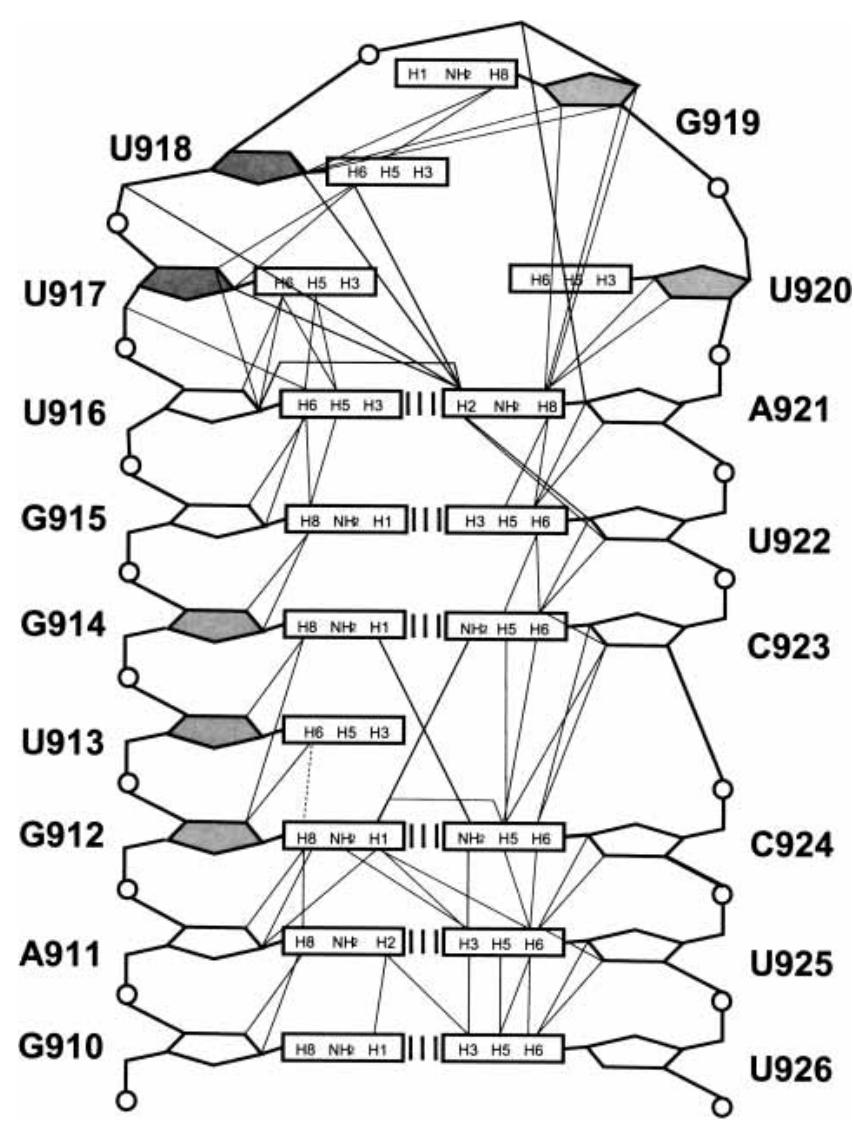

FIGURE 3. Schematic representation of NOE data collected on NRS23 (only residues 910-926 are shown). Thin lines represent interresidue NOEs. The ribose pucker is represented by dark filling for C2' endo, gray for mixed $2 \mathrm{C}^{\prime} / \mathrm{C}^{\prime}$ endo, and open for $\mathrm{C}^{\prime}$ endo. An extremely weak NOE is represented by a broken line.

mental data, possibly because of the flexibility of the bulge. The residues around U913 stack and form part of a helix that has an $\sim 15^{\circ}$ bend in the helical axis around the bulge in the RDC-refined structure. The bulged U913 appears to be readily available for intermolecular base-pairing with G17 of U11 snRNA (Hall and Padgett 1994). The presence of this bulge may contribute to the instability of the following 3 bp (914-916) proximal to the tetraloop. The HNN-COSY cross-peaks (Fig. 4) and the imino resonance peaks associated with these 3 bp are weak, and the U922 imino resonance is not detected. This indicates an increased solvent exchange in this region and, presumably, destabilization of the base-pairing within the loop.

Like the bulge, the 917-920 UUGU tetraloop (Fig. 5) is more dynamic than the base-paired residues. Although it is partially structured by stacking of U917 on U916 in some of the lowest-energy structures, it is not a compact structure. There is no particular intramolecular interaction that would hinder the loop from forming intermolecular interactions. Although the interresidue NOEs suggest that U916 and U917 stack, the use of the RDC restraints prevents them from stacking in some of the convergent structures. Furthermore, U917 has a C2' endo character, indicating that it does not stack in a regular A-form helix. Its position variability suggests a conflict between the NOEs, indicating the stacking, and the ribose $\mathrm{C} 2$ ' endo pucker torsion angles. The two sets of conformations for U917 seen in the structures may not be present in a stable form. The preliminary measurements of ${ }^{13} \mathrm{C} 8-{ }^{1} \mathrm{H} 8$ of $\mathrm{G} 919$ show an attenuated $\mathrm{T}_{1 \rho}$ and an elevated $\mathrm{T}_{1}$ compared with those in the stem region, indicating that G919 is in anisotropic slow motion compared with residues in the stem. Although a conclusive assessment of the dynamics of the tetraloop will have to come from complete relaxation measurements using site-specific labeling to remove the complication due to ${ }^{13} \mathrm{C}-{ }^{13} \mathrm{C}$ homonuclear cross-relaxation, the line widths, signal intensities, and few interresidue NOEs detected suggest this region is dynamic compared with the stem of the molecule. As a result, the tetraloop has poor RMSDs between the measured RDCs and those calculated on the basis of the structures, even when one of two alignment tensors in the

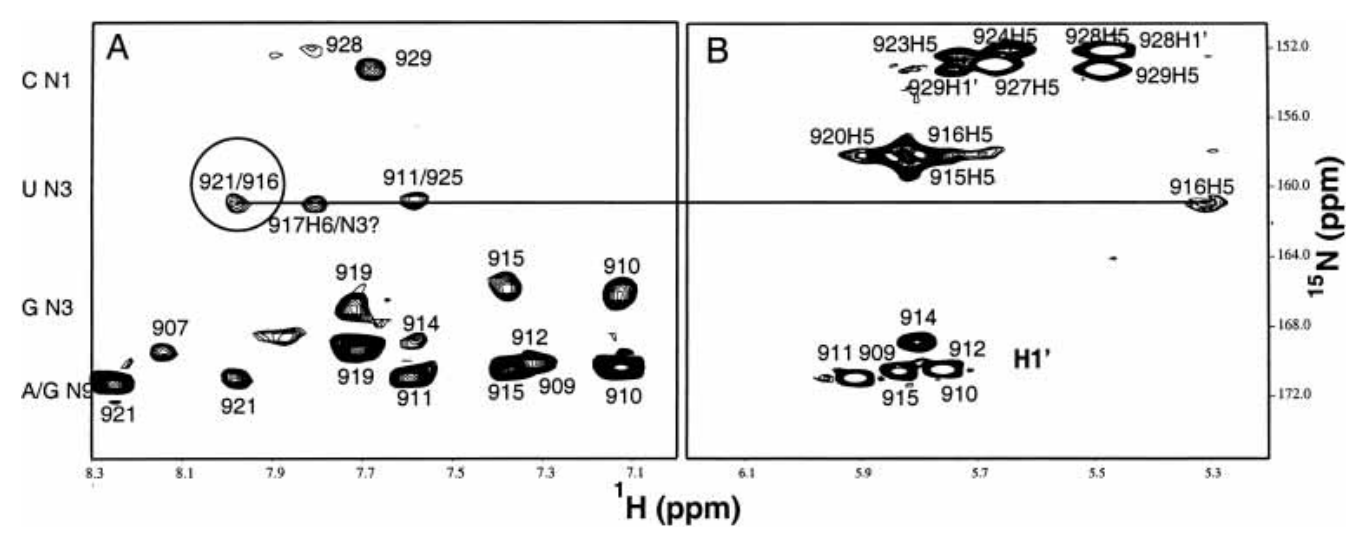

FIGURE 4. HNN-COSY spectrum of NRS23 showing the A H2 to U N3 region $(A) \cdot{ }^{15} \mathrm{~N}-{ }^{1} \mathrm{H}$ HMQC optimized for long-range correlations showing the H5/N1 region of $\mathrm{U}(B)$. The horizontal line connects the interresidue correlation between A921 H2 and U916 N3 (circled) and the intrabase correlation between U916 $\mathrm{H} 5$ and N3. The H8 to N9 and G N3 correlations are seen in the HNN-COSY; some N9-H1' and N1-H5/H1' correlations are seen in the HMQC. 


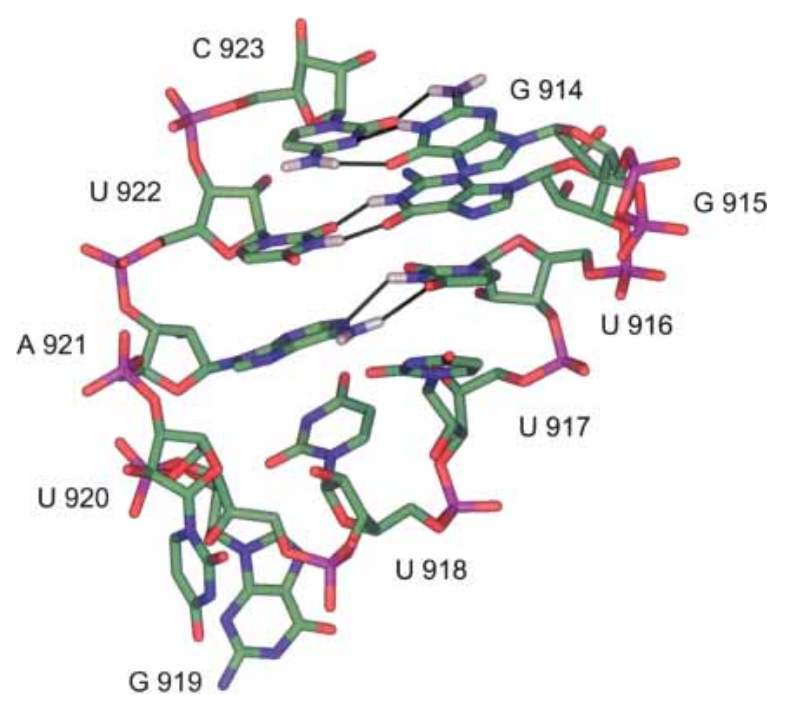

FIGURE 5. The loop residues $914-923$ from the minimized average structure of NRS23. This structure was calculated from the 15 lowestenergy NRS23 structures. Note that the top of the loop is closed by 3 bp. The UUGU tetraloop adopts no particular structure and presumably is ready for intermolecular interaction.

two-alignment tensor approach is optimized for the latter residues.

\section{Stability of NRS23 and U913-deleted NRS23 determined by UV melting}

The bulged U913 of NRS23 disrupts the helix and is predicted to destabilize the structure of NRS23. This prediction was tested by thermal denaturation experiments, monitored by UV spectroscopy. NRS23 RNA was compared with a U913 deletion mutant of NRS23 (NRS23 $\Delta 913$ ). Melting curves for each hairpin were measured at $260 \mathrm{~nm}$ in a thermoelectrically controlled spectrophotometer with a buffer containing $5 \mathrm{mM}$ sodium cacodylate ( $\mathrm{pH}$ 6.4) and 50 $\mathrm{mM} \mathrm{NaCl}$. The temperature was scanned at a heating rate of $0.5^{\circ} \mathrm{C} / \mathrm{min}$ and the unfolding of each hairpin was found to be reversible under these conditions. Transition temperature $\left(\mathrm{T}_{\mathrm{m}}\right)$ and van't Hoff enthalpy $(\Delta \mathrm{H})$ values were determined from the first derivatives using procedures described earlier (Laing and Draper 1994). $\mathrm{T}_{\mathrm{m}}$ and $\Delta \mathrm{H}$ values were also obtained by fitting the melting curves to a two-state model as described earlier (Marky and Breslauer 1987). The error in the $\mathrm{T}_{\mathrm{m}}$ determination is $<0.5^{\circ} \mathrm{C}$ from the experimental variation that we measured in triplicate melts.

The $\mathrm{T}_{\mathrm{m}}$ for NRS23 was determined to be $59.2^{\circ} \mathrm{C}$ (Fig. 6). Deletion of residue U913 from NRS23 increased the melting temperature $\sim 14 \pm 0.5^{\circ} \mathrm{C}$ and the $\Delta \mathrm{H} \sim 12 \mathrm{kcal} /$ mole to 69 $\mathrm{kcal} / \mathrm{mole}$ (Fig. 6). The estimated difference in $\Delta \mathrm{G}$ between the wild-type NRS sequence and the U913-deleted NRS23 is $+3.8 \mathrm{kcal} / \mathrm{mole}$. Thus, the melting data confirmed the prediction that the bulged U913 residue destabilizes the stemloop structure of the wild-type NRS23. Its deletion generates a more stable stem-loop structure without changing any of the existing base pairs in NRS23. A structure determination of the U913-deleted NRS23 RNA is currently under way.

\section{Interaction of NRS RNA with U1 snRNA}

Residues 913-920 of the NRS bear a 5/8 identity to a consensus 5' splice site (Fig. 1A; Hibbert et al. 1999; McNally and McNally 1999). The three nonconsensus residues are the U's at residues 913, 917, and 918 (positions $-2,+3$, and +4 , respectively). Each of these U's is poised to interact with a $U$ or $\Psi$ in U1 snRNA (Fig. 1B). It has previously been shown that these interactions are critical for NRS-mediated splicing suppression. Mutation of any of these U's to A abolishes splicing suppression and converts the NRS into a functional 5' splice site (Paca et al. 2001). Conversely, mutating any of these U's to a $\mathrm{C}$ abolishes splicing suppression but does not convert the NRS into a functional 5 ' splice site (Paca et al. 2001). We have titrated the NRS23 RNA with the $5^{\prime}$ 10-residue sequence AUAC $\Psi \Psi$ ACCU (U1-5') of U1 snRNA and monitored the interaction between the two RNAs using HSQC spectra. Our preliminary results support the notion that U1-5' RNA interacts with the loop of

A

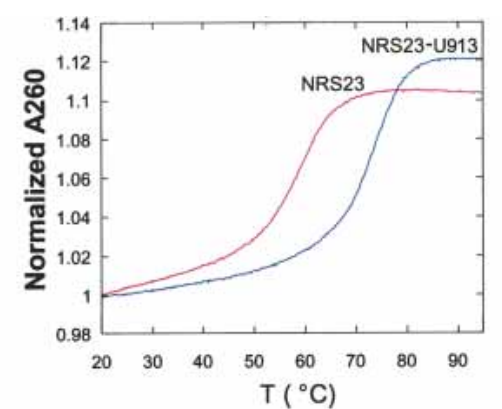

B

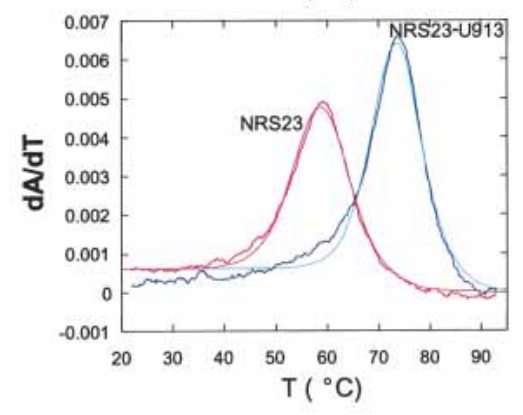

\begin{tabular}{|c|cccc|}
\hline Hairpin & $\begin{array}{c}\mathrm{Tm} \\
\left({ }^{\circ} \mathrm{C}\right)\end{array}$ & $\begin{array}{c}\Delta \mathrm{G} \\
(\mathrm{kcal} / \text { mole) }\end{array}$ & $\begin{array}{c}\Delta \mathrm{H} \\
\text { (kcal/mole) }\end{array}$ & $\begin{array}{c}\Delta \mathrm{S} \\
\text { (mole/cal-K) }\end{array}$ \\
\hline NRS 23 & 59.2 & 3.8 & 57 & 172 \\
NRS 23 $\Delta 913$ & 72.9 & 7.2 & 69 & 199 \\
\hline
\end{tabular}

FIGURE 6. Melting profiles show that NRS23 is less stable than NRS23 $\Delta$ U913. Melting curves $(A)$ and their first derivatives $(B)$ of NRS23 and the NRS23 $\Delta$ U913 mutant, respectively. Dark blue and red, experimental; pink and light blue, fit curves. The thermodynamic data are listed in the embedded table. The melting temperature has an error of $\pm 0.5^{\circ} \mathrm{C}$. 
NRS23, whereas the base pairs in the stem remain largely unperturbed (data not shown).

The three U's exist in interesting locations in the NRS23 3D structure. U913 is bulged from the helix and U917 and U918 are part of the tetraloop (Figs. 2, 5). Because the $3 \mathrm{bp}$ within the loop must be unwound before U1 can base-pair, the presence of the bulged residue may promote U1 binding by partially destabilizing the otherwise continuous helix. To address this issue, we tested U1 snRNP binding to four NRS RNA fragments spanning nucleotides 902-939. The wildtype NRS sequence and $\Delta 913$ were compared with a mutant that splices well (UU917/918AA) and another mutant that neither splices nor suppresses splicing (UU917/918CC). The RNAs were covalently linked to agarose beads via their $3^{\prime}$ ends and used in an affinity selection assay in HeLa cell nuclear extract, carried out in the absence of ATP and $\mathrm{Mg}^{+2}$ (Caputi et al. 1999). The affinity-selected RNA was harvested and Northern analysis performed to measure U1 snRNP binding (Fig. 7A). As a control, an aliquot of each affinity-selected sample was analyzed by SDS-PAGE and Coomassie staining to demonstrate that the nonspecific binding of proteins was equivalent between the samples (data not shown).

Affinities for U1 snRNP binding were calculated by quantitating the relative amount of ${ }^{32} \mathrm{P}$-labeled $\mathrm{U} 1$ antisense riboprobe binding to the selected RNAs in each case. The background binding to the beads was subtracted and the average values normalized to that of the wild-type NRS in each trial. The results of this normalization are shown in Figure 7B. The $\Delta 913$ mutant, which stabilized the helix (Fig.

A

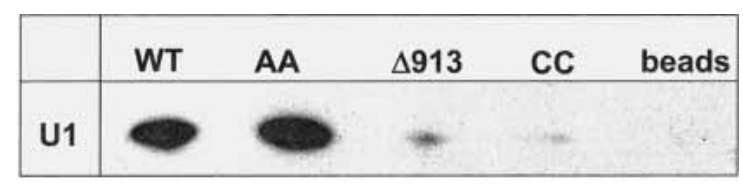

B

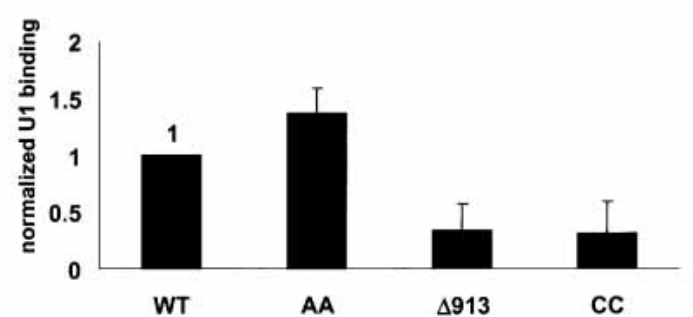

FIGURE 7. Binding of U1 snRNP to the NRS requires destabilizing the double-stranded helix. (A) Northern analysis of U1 snRNA affinity selected from HeLa nuclear extract, with wild-type (WT) NRS RNA, the UU917/918AA mutant that is capable of splicing (AA), the U913 deletion mutant, and the nonfunctional UU917/918CC mutant (CC). (B) Relative U1 snRNP affinities of the wild-type NRS and the mutants. The background binding to the beads was subtracted, and each trial was normalized to the WT levels. The average of three experiments is presented.
6), reduced binding of U1 snRNP to $33 \%$ of the wild-type level (Fig. 7B). The binding to this single-base deletion mutant was similar to that of the nonfunctional UU917/918CC mutant (30\%). In contrast, the UU917/918AA mutant, which is capable of splicing, bound slightly more U1 snRNP $(136 \%)$ than the wild-type NRS. This experiment shows that mutations affecting the structure of the RNA, as well as its sequence complementarity to U1 snRNA, can affect binding of U1 snRNP.

\section{DISCUSSION}

We have analyzed the solution structure of a 23-nt RNA hairpin, NRS23, that interacts with U1 and U11 snRNPs to control alternative splicing and generate the proper balance of spliced and unspliced retroviral RNAs. Secondary structure analysis showed that NRS23 contained a 6-bp stem and an 11-residue loop. Disruption of the stem by mutagenesis caused a loss of splicing regulation in vivo; this was restored by compensatory mutations that restored the stem structure (O'Sullivan 2001). Residues that base-pair with U1 snRNA were contained within the loop. Determination of the $3 \mathrm{D}$ structure of NRS23 by NMR spectroscopy revealed a 6-bp stem, a bulged U, 3 bp across the loop, and a dynamic UUGU tetraloop. The structure of NRS23 provides insight into the regulation of alternative splicing in this system.

The stability of the NRS23 helix is likely to be central to RSV regulation of alternative splicing. The ${ }^{31} \mathrm{P}$ spectrum of the NRS23 indicates no U-turn type sharp twist for the $\alpha$ or $\xi$ torsion angles. The measured backbone torsion angles do not deviate greatly from an A-form type helix, with the exception of the ribose pucker for the bulge, its flanking residues, and the tetraloop. The loop residues appear to exist in a closed conformation in solution, and this loop must be unwound before U1 snRNA can base-pair with it. The bulged U913 serves to destabilize the helix and likely allows this unwinding to be more energetically favorable. Our results show that NRS23 $\Delta 913$ is more stable than NRS23 (Fig. 6), suggesting that deletion of the bulged $U$ at position 913 results in the formation of better stacking interactions in the helical stem of the hairpin. This is consistent with the larger $\Delta \mathrm{H}$ values of NRS23 $\Delta 913$, although the large errors associated with van't Hoff enthalpies make it difficult to further analyze the enthalpic effects of this deletion. The formation of a helix with better stacking interactions results in a decrease in the conformational freedom of NRS23 $\Delta 913$, consistent with the observed increase in $\Delta \mathrm{S}$ of unfolding. The $\Delta \mathrm{G}_{37}$ penalty of $3.4 \mathrm{kcal} / \mathrm{mole}$ for the incorporation of a single bulge in the stem of NRS23 is in excellent agreement with the average bulge destabilization of $3.6 \mathrm{kcal} / \mathrm{mole}$ reported earlier (Znosko et al. 2002).

The hyperstable $\Delta 913$ mutant of NRS23 had a decreased ability to bind U1 snRNP (Fig. 7). This is interesting in light of the fact that the wild-type NRS and the $\Delta 913$ mutant share the same Watson-Crick base pairs with U1 snRNA. 
The regulatory problem facing RSV is to maintain pools of both spliced and unspliced RNA. Therefore, the NRS must not suppress splicing of every full-length RNA. The presence of a moderately destabilized helix appears to allow for an optimal affinity of U1 snRNP for the loop. The mutant NRS sequence that splices has U/A substitutions within the tetraloop, suggesting that the structure determined for NRS23 may closely resemble that of a $5^{\prime}$ splice site. The U913 bulge may also facilitate the interaction between the NRS and U11 snRNP (Gontarek et al. 1993).

Like the bulge, the UUGU tetraloop has more dynamic characteristics than the base-paired residues (Figs. 2, 5). This less structured tetraloop is in a sharp contrast to the well-known GNRA, CUYG, and UNCG classes of tetraloops, which serve as ultrastable structural elements and nucleation sites for RNA folding (Jucker et al. 1996; Molinaro and Tinoco 1995). The UUGU tetraloop in the NRS, on the other hand, is poised to interact with the U1 and U11 snRNPs as required for its regulatory function. It is worth noting that a UUGU tetraloop is also found in hairpins near the $5^{\prime}$ terminus of the spleen necrosis virus RNA (Roberts and Boris-Lawrie 2003). This tetraloop, together with Urich bulges, is speculated to be a binding site for host factors that regulate the translation of the viral RNA. In conclusion, it appears that UUGU tetraloop is distinguished from the well-known class of tetraloops in terms of structure, stability, and function, being a dynamic structure that interacts with other RNAs.

\section{MATERIALS AND METHODS}

\section{RNA samples}

DNAse I, pyruvate kinase, myokinase, guanylate kinase, P1 nuclease, and unlabeled 5' nucleoside triphosphates (NTPs) were purchased from Sigma Chemical. T7 RNA polymerase was prepared as described (Davanloo et al. 1984). In some instances, ${ }^{13} \mathrm{C} /{ }^{15} \mathrm{~N}$ enriched NTPs were purchased from Spectra Isotopes (CIL) and MarTech. The $99 \%\left\{{ }^{13} \mathrm{C}\right\}$ glucose and $98 \%\left\{{ }^{15} \mathrm{~N}\right\}$-labeled ammonium sulfate were purchased from CIL. RNAse-free pf1 phage was purchased from Asla (Riga).

Unlabeled RNA was purchased from Dharmacon or synthesized by in vitro transcription (Batey et al. 1992; Niknonowicz et al. 1992). ${ }^{13} \mathrm{C} /{ }^{15} \mathrm{~N}$ or ${ }^{15} \mathrm{~N}$ isotopic enrichment RNAs were synthesized by in vitro transcription using labeled NTPs that were either purchased or prepared from ribosomal RNA as described (Batey et al. 1992; Niknonowicz et al. 1992). Transcribed RNA molecules were purified using preparative gel electrophoresis in $10 \%(\mathrm{w} / \mathrm{v})$ polyacrylamide/7M urea followed by electroelution on a Schleicher and Schuell elution chamber. The RNA was then precipitated and spin filtered once with $2 \mathrm{~mL} 1 \mathrm{M} \mathrm{NaCl}$ and $50 \mathrm{mM} \mathrm{NaPi} \mathrm{(pH} \mathrm{6.5)}$ and three times with $2 \mathrm{~mL}$ of the NMR buffer of $25 \mathrm{mM} \mathrm{NaCl}, 10$ $\mathrm{mM} \mathrm{NaPi}$ ( $\mathrm{pH} 6.5$ ), and $0.05 \mathrm{mM}$ EDTA. The identities of the samples were confirmed by molecular weight through MALDITOF mass spectrometry. The samples were taken to a volume of $350 \mu \mathrm{L}$, lyophilized, and resuspended in $99.96 \% \mathrm{D}_{2} \mathrm{O}$ or $95 \%$ $\mathrm{H}_{2} \mathrm{O}-10 \% \mathrm{D}_{2} \mathrm{O}$ for experiments detecting nonexchangeable or exchangeable protons, respectively. The samples consisted of $100-$
200 ODs $(\sim 1.3-2.6 \mathrm{mM})$ of unlabeled material, 130 ODs $(\sim 1.7$ $\mathrm{mM})$ of ${ }^{15} \mathrm{~N}$-labeled material, and $115-130 \mathrm{~A}_{260}$ ODs $(\sim 1.5-1.7$ $\mathrm{mM})$ of ${ }^{13} \mathrm{C} /{ }^{15} \mathrm{~N}$-labeled RNA. The pf1 phage was taken into the NMR buffer by spin filtering on $50-\mathrm{kDa}$ cutoff Vivaspin concentrators and mixed with RNA in the same buffer to a final phage concentration of $\sim 21 \mathrm{mg} / \mathrm{mL}$. The unlabeled U1 snRNA fragment of sequence AUA $\Psi \Psi A C C U$ was purchased from Dharmacon and resuspended in deionized $\mathrm{H}_{2} \mathrm{O}$ to a concentration of $4.24 \mathrm{mM}$. An NRS23 sample in the NMR buffer at a concentration of $\sim 0.35 \mathrm{mM}$ was titrated with this molecule, to a molar ratio of 0.5 in the NMR tube.

RNAs used for affinity selection were in vitro transcribed using two DNA oligonucleotides as the template. The sense strand of the T7 promoter region, 5'-taatacgactcactataggg-3', was hybridized with one of four oligonucleotides, each of which contain the antisense strand of the T7 promoter, followed by the nucleotides 902-939 of the NRS. The following list of oligonucleotides has the T7 antisense strand underlined:

wild-type NRS, 5'-acccccgccagggaaggatacaaaccactccccacataccetata gtgagtcgtatta- $3^{\prime}$;

$\Delta 913$ mutant, $5^{\prime}$ - accccegccagggaaggatacaaaccctccccacataccctatagt gagtcgtatta- $3^{\prime}$;

AA mutant, 5' -acccccgccagggaaggatacttaccactccccacataccctatagtga gtcgtatta- $3^{\prime}$;

CC mutant, 5' -acccccgccagggaaggatacggaccactccccacataccctatagtga gtcgtatta- $3^{\prime}$

For the affinity selection, total RNA from the in vitro transcription reaction was loaded onto an $8-\mathrm{M}$ urea, $20 \%$ polyacrylamide gel and gel purified via UV shadowing. The gel slices were eluted overnight at $4^{\circ} \mathrm{C}$ in RNA elution buffer: $0.5 \mathrm{M}$ ammonium acetate, $0.1 \%$ SDS, $1 \mathrm{mM}$ EDTA.

\section{Secondary structure determination}

Nuclease probing with RNases T2 and V1 was as described by Mougin et al. (2002), except that it was performed on $3^{\prime}$-end labeled RNA. Lead cleavages were performed in $50 \mathrm{mM}$ HEPES$\mathrm{KOH}$ buffer ( $\mathrm{pH} 7.5$ ), $50 \mathrm{mM} \mathrm{K}$ acetate, and $20 \mathrm{mM} \mathrm{Mg}$ acetate, in the presence of 4 or $20 \mathrm{mM} \mathrm{Pb}(\mathrm{OAc})_{2}$ for $5 \mathrm{~min}$ at $20^{\circ} \mathrm{C}$. Reactions were stopped by addition of EDTA (250 mM final). Direct analysis of the fragments produced was made after migration on a $15 \%$ acrylamide-urea gel.

\section{Affinity selection assay}

Affinity selection was carried out essentially as described in Caputi et al. (1999) with the following modifications. One nanomole of target RNA was covalently linked to the beads. After the affinity selection protocol was complete, the beads were resuspended in proteinase $\mathrm{K}$ digestion buffer $(10 \mathrm{mM}$ Tris at $\mathrm{pH} 7.2,0.5 \mathrm{mM}$ EDTA, $0.5 \%$ SDS) and $50 \mu \mathrm{g}$ of proteinase $\mathrm{K}$ was added for $30 \mathrm{~min}$ at $37^{\circ} \mathrm{C}$. Next, the beads were boiled and the RNA was extracted with phenol:chloroform:isoamyl alcohol and precipitated with ethanol. Northern analysis was carried out as previously described (Gontarek et al. 1993).

\section{UV melting}

The thermal denaturation of NRS23 and NRS23 2 U913 was followed by UV spectroscopy. Absorbance versus temperature pro- 
files (melting curves) for each hairpin were measured at $260 \mathrm{~nm}$ with a thermoelectrically controlled Cary 400 Bio spectrophotometer (Varian Inc.). All experiments were conducted in $5 \mathrm{mM}$ sodium cacodylate ( $\mathrm{pH}$ 6.4) and $50 \mathrm{mM} \mathrm{NaCl}$. The temperature was scanned at a heating rate of $0.5^{\circ} \mathrm{C} / \mathrm{min}$, and the unfolding of each hairpin was found to be reversible under these conditions. $\mathrm{T}_{\mathrm{m}}$ and $\Delta \mathrm{H}$ values were determined from the first derivatives using procedures described earlier (Laing and Draper 1994). $\mathrm{T}_{\mathrm{m}}$ and $\Delta \mathrm{H}$ values were also obtained by fitting the melting curves to a twostate model as described earlier (Marky and Breslauer 1987). The error in the $\mathrm{T}_{\mathrm{m}}$ determination is $<0.5^{\circ} \mathrm{C}$ from the experimental variation that we measured in triplicate melts. However, it is worth noticing that systematic deviations in the fits, because of the presence of small deviations from a two-state behavior (especially evident at low temperatures) may increase the error in the determination of the $\mathrm{T}_{\mathrm{M}}$. Nevertheless, from the values obtained from the two different fittings, the errors in the $\mathrm{T}_{\mathrm{m}} \mathrm{s}$ do not exceed $0.5^{\circ} \mathrm{C}$. Free energies at $37^{\circ} \mathrm{C}\left(\Delta \mathrm{G}_{37}\right)$ were calculated according to $\Delta \mathrm{G}_{37}=\Delta \mathrm{H}\left(1-310.15 / \mathrm{T}_{\mathrm{m}}\right)$. Entropy values $(\Delta \mathrm{S})$ were calculated from the Gibbs equation $\Delta \mathrm{G}=\Delta \mathrm{H}-\mathrm{T} \Delta \mathrm{S}$.

\section{NMR spectroscopy, chemical shift assignments, and structural constraints}

Homonuclear ${ }^{15} \mathrm{~N}$ or ${ }^{15} \mathrm{~N} /{ }^{13} \mathrm{C}$ heteronuclear NMR spectra were recorded in Varian INOVA spectrometers, operating at 500-, 600-, and $800-\mathrm{MHz}$ proton frequencies and equipped with triple resonance probe heads and $\mathrm{z}$-axis pulse field gradients. The $500-\mathrm{MHz}$ spectrometer is equipped with a Varian cryoprobe. Spectra involving ${ }^{13} \mathrm{C}$ and ${ }^{31} \mathrm{P}$ channels were recorded on a Bruker DRX 500 spectrometer equipped with a triple resonance HCP probe and z-axis pulse field gradients. Spectra involving $\mathrm{H}_{2} \mathrm{O}$ exchangeable resonances were collected at $15^{\circ} \mathrm{C}$ and those involving nonexchangeable protons at $25^{\circ} \mathrm{C}$. The $\mathrm{H}_{2} \mathrm{O}$ signal was suppressed using $\mathrm{Z}$ gradient pulses and WATERGATE or gradient double-echo sequences. In the case of imino proton HMQC spectra, it was suppressed using 1331 read pulses optimized for a maximum signal at 12.5 ppm. ${ }^{1} \mathrm{H}$ resonances were referenced to DSS and ${ }^{13} \mathrm{C}$ and ${ }^{15} \mathrm{~N}$ were referenced to $\mathrm{H}_{2} \mathrm{O}$ internally; ${ }^{31} \mathrm{P}$ was referenced to ${ }^{31} \mathrm{P}$ signal of $\mathrm{PO}_{4}{ }^{-3}$. Broadband decoupling during acquisition was done using Wurst80 with $\gamma \mathrm{B}_{2}=12.79 \mathrm{ppm}^{*} \gamma_{\mathrm{C}} \mathrm{B}_{0}$ for ${ }^{13} \mathrm{C}$ and GARP with $\gamma \mathrm{B}_{2}=21.31 \mathrm{ppm}^{*} \gamma_{\mathrm{N}} \mathrm{B}_{0}$ for ${ }^{15} \mathrm{~N}$. The States-TPPI method was used for quadrature detection. Detection in indirectly detected dimensions was normally delayed by a half dwell time.

Spectra were processed in SGI workstations with the nmrPipe software package (Delaglio et al. 1995) and analyzed with nmrDraw and nmrView (Johnson and Blevins 1994). The spectra were typically linear, predicted to double the size of the data in the indirectly detected dimensions and apodized with a sinebell function and zero filled to twice the number of points. The spectra used for RDC determination were zero-filled in the dimensions used to measure splittings to a digital resolution of $1.56-3.3 \mathrm{~Hz} /$ point for ${ }^{1} \mathrm{H}$ and $2 \mathrm{~Hz} /$ point for ${ }^{15} \mathrm{~N}$; dimensions in these spectra were apodized using a gaussian function with $30-\mathrm{Hz}$ line broadening with the exception of the ${ }^{15} \mathrm{~N}$ dimension, which was apodized with $20-\mathrm{Hz}$ line broadening.

The assignment procedure was based on standard protocols (Nikonowicz and Pardi 1993; Marino et al. 1997; Lukavsky and Puglisi 2001). All of the nonexchangeable base ${ }^{1} \mathrm{H}$ and ${ }^{13} \mathrm{C}$ reso- nances were assigned. A sequential walk along the RNA was done on the basis of the intra- and interresidue $\mathrm{H}^{\prime}-\mathrm{H} 6 / \mathrm{H} 8$ NOEs, using $3 \mathrm{D}{ }^{13} \mathrm{C}$-edited NOESY-HSQC experiments (Nikonowicz and Pardi 1993) together with 2D-NOESY spectra, all with 300msec mixing times. The exchangeable resonance assignments were also obtained through an NOE sequential walk performed on a $2 \mathrm{D}$ NOESY (200-msec mixing time) and by their ${ }^{15} \mathrm{~N}$ chemical shifts in $2 \mathrm{D}^{15} \mathrm{~N} /{ }^{1} \mathrm{H}$ HMQC (Mueller 1979) and HSQC (Kay et al. 1992) spectra. ${ }^{31} \mathrm{P}$ resonances were assigned using a 3D single-quantum coherence HCP experiment (Marino et al. 1995). Watson-Crick base pairs were identified through the downfield shift of the $\mathrm{NH}$ and $\mathrm{NH}_{2}$ resonances, and by $\mathrm{G}$-imino to $\mathrm{C}$-amino and $\mathrm{U}$-imino to A $\mathrm{H} 2{ }^{1} \mathrm{H}-{ }^{1} \mathrm{H}$ cross-peaks in $2 \mathrm{D}$ NOESY spectra. The base pairs were confirmed through the use of ${ }^{2 \mathrm{~h}} \mathrm{~J}_{\mathrm{NN}} \mathrm{HNN}-\mathrm{COSY}$ experiments optimized for the G H1-C N3 and U N3-A H2 correlations (Dingley and Grzesiek 1998; Hennig and Williamson 2000).

NOE distance constraints were derived from 2D NOESY (200and 300-msec mixing time) and $3 \mathrm{D}{ }^{13} \mathrm{C}$-edited NOESY-HSQC (300-msec mixing time) spectra (Nikonowicz and Pardi 1993). For the exchangeable resonances, NOE cross-peaks were identified in a 200-msec NOESY. NOE cross-peak intensities were classified as very strong, strong, medium, weak, and very weak using the intensities of base H5-H6 (2.4 $\AA$ ) and of ribose $\mathrm{H}^{\prime}-\mathrm{H} 2^{\prime}(2.8-3 \AA)$ as references and allotted semiquantitative distance constraints of 3, 4, 5, 6, and $7 \AA$, respectively (Varani et al. 1996). Cross-peaks observed only in the 300 -msec mixing time 2D NOESY were classified as extremely weak. No lower bounds for the NOE constraints were used. The distance constraints for the exchangeable protons did not include the very strong category, except for the proton pairs $\mathrm{H} 2$-imino and imino-amino of A-U and G-C base pairs, respectively. No intraresidue ribose-to-ribose NOE constraints were used. The hydrogen bond distance restraints for the base pairs were set as $2.9 \pm 0.3 \AA$ between donor and acceptor atoms and $2.02 \pm 0.2 \AA$ between acceptor and hydrogen atoms. The hydrogen bond constraints were introduced together with the NOE distance constraints.

Torsion angle constraints were estimated using Karplus equations from ${ }^{3} \mathrm{~J}$ coupling constant measurements. These were obtained from spin echo difference ${ }^{13} \mathrm{C}$ CT-HMQC (Hu et al. 1999; Szypersky et al. 1999) and ${ }^{13}$ C CT-HSQC (Legault et al. 1995) in ${ }^{13} \mathrm{C}$-labeled samples as well as ${ }^{1} \mathrm{H}_{-}{ }^{1} \mathrm{H}$ DQF-COSY (Rinkel and Altona 1987) and ${ }^{31} \mathrm{P}-{ }^{1} \mathrm{H}$ HETCOR in unlabeled samples. The backbone torsion angles of loop residues 917-920 were left unconstrained because of evidence of increased dynamics in that region with the exception of the ribose pucker of 917-918. More details are presented in Supplementary Material.

The RDCs were taken as the difference between the corresponding measurements of anisotropic and isotropic media conditions. Riboses ${ }^{1} \mathrm{H}_{-}{ }^{13} \mathrm{C}$ couplings were measured from peak splittings in the directly detected ${ }^{1} \mathrm{H}$ dimension on the ribose ${ }^{1} \mathrm{H}$ and ${ }^{13} \mathrm{C}$ spectral region on a $3 \mathrm{D} \mathrm{HCCH}-\mathrm{COSY}$-relay IPAP (Vallurapalli and Moore 2002). Base ${ }^{1} \mathrm{H}_{-}{ }^{13} \mathrm{C}$ couplings were measured from $2 \mathrm{D}$ ${ }^{13} \mathrm{C}-{ }^{1} \mathrm{H}$ TROSY upfield and downfield ${ }^{1} \mathrm{H}$ cross-peaks with the downfield ${ }^{13} \mathrm{C}$ component (Weigelt 1998). ${ }^{13} \mathrm{C}-{ }^{13} \mathrm{C}$ one-bond RDCs were measured from ${ }^{1} \mathrm{H}^{-13} \mathrm{C}$ HSQC experiments as described by McCallum and Pardi (2003), except that all measurements were done in the ${ }^{13} \mathrm{C}$ dimension with the appropriate selective ${ }^{13} \mathrm{C}$ decoupling. Imino couplings were measured in the ${ }^{15} \mathrm{~N}$ dimension on a $2 \mathrm{D}^{15} \mathrm{~N}-{ }^{1} \mathrm{H}$ HSQC (Hansen et al. 2000). The initial axial component of the alignment tensor, $D_{a}$, was estimated from 
the largest absolute value of the measured set of RDCs (Fig. 8A). After determining the initial rhombicity from the histogram of normalized RDCs (Clore et al. 1998), R and $D_{a}$ were optimized by a grid search using the Xplor refinement protocol described following in the absence of the DELPHIC force field and excluding the RDC measurements for residues $917-920$ in the loop. $D_{a}$ was determined as $-14.5 \mathrm{~Hz}$ (ribose $\mathrm{CH}$ ) and $\mathrm{R}$ as 0.4 . The deuterium quadrupole splitting was used to correct $D_{a}$ for different pfl phage concentrations. $D_{a}$ was set for the $\mathrm{NH}$, the aromatic $\mathrm{CH}$, the ribose CC, and the pyrimidines C4C5 and C5C6 as $\left(\gamma_{\mathrm{P}} \gamma_{\mathrm{Q}} \mathrm{r}_{\mathrm{CH}}{ }^{3}\right) /$ $\left(\gamma_{\mathrm{C}} \gamma_{\mathrm{H}} \mathrm{r}_{\mathrm{PQ}}{ }^{3}\right)$ being $\mathrm{r}_{\mathrm{CH}}$ the interatomic distance of the $\mathrm{CH}$ in the ribose (McCallum and Pardi 2003). The force constants for the RDC constraints were scaled relative to that for $\mathrm{NH}$ as $\left(\gamma_{\mathrm{N}} \gamma_{\mathrm{H}} \mathrm{r}_{\mathrm{PQ}}{ }^{3}\right) /\left(\gamma_{\mathrm{P}} \gamma_{\mathrm{Q}} \mathrm{r}_{\mathrm{NH}}{ }^{3}\right)$. The RDC constraints were given a range with no energy penalty of $\pm 0.6 \mathrm{~Hz}$.

\section{Structure calculations and refinement}

The initial NRS structure was calculated using a reported protocol (Cabello-Villegas et al. 2002). The constraints included 423 dis-
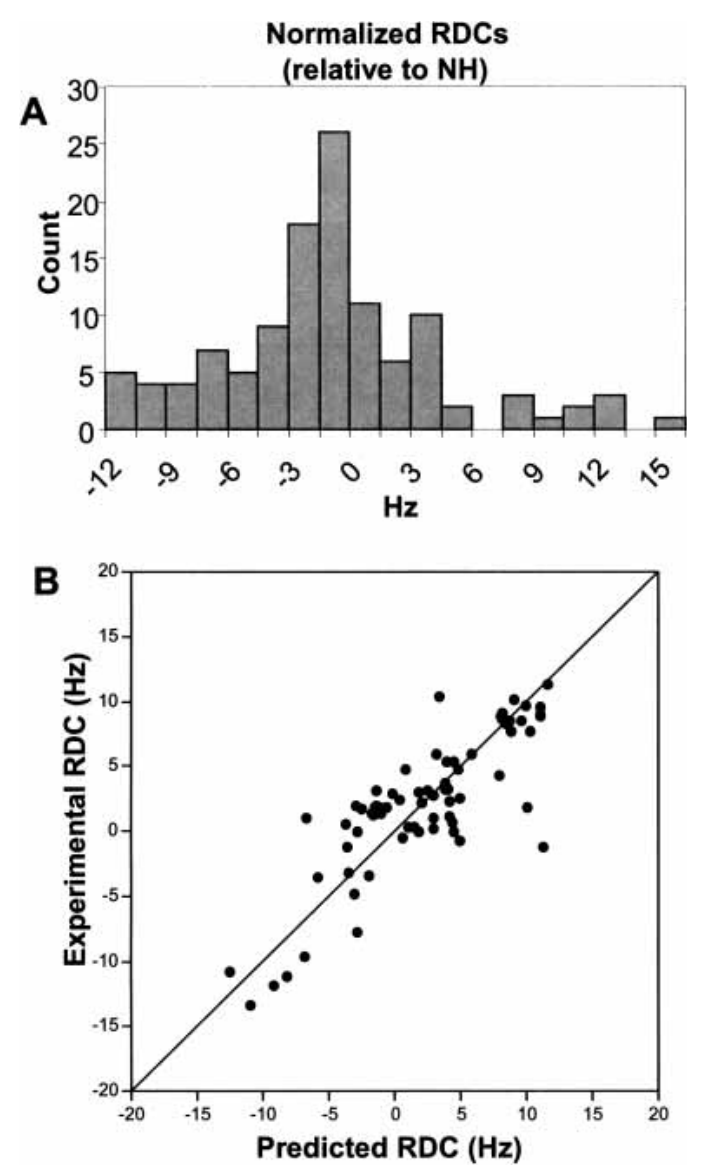

FIGURE 8. Histogram of the RDC distribution $(A)$ and calculated versus experimental RDCs for NRS23 (Pearson's plot, $B$ ). The onebond $\mathrm{C}-\mathrm{C}$ and $\mathrm{C}-\mathrm{H}$ RDCs are normalized to the NH couplings. Pearson's plot of experimental RDC vs. the values calculated after best fitting the alignment tensor to the lowest-energy structure refined without RDC constraints. The Pearson's coefficient is $\sim 0.83$. The RDCs of the tetraloop residues were excluded because of their dynamic behavior. tance restraints, among which 377 are NOE constraints, 46 hydrogen bond constraints, and 63 torsion angle restraints. The 10 lowest-energy structures have no NOE and torsion angle violations $>0.5 \AA$ and $5^{\circ}$, respectively. The minimized average of the convergent structures was used as an initial structure for a refinement with RDCs (Schwieters et al. 2003). The final ensemble of structures was calculated using a single alignment tensor and RDCs of the stem region. The DELPHIC potential for relative positions of close bases and for torsion angles in nucleic acids was turned on for the residues, excluding the budged U913 and the loop residues (917-920) in the last refinement procedure using the same protocol (Clore and Kuszewski 2003; Schwieters et al. 2003). We also performed a refinement with dual alignment tensors. In this case, the calculation used two alignment tensors simultaneously, one for the upper loop residues 916 to 921 and the other one for the rest of the molecule. The values for $D a$ and $\mathrm{R}$ for the second tensor were determined by a grid search to be $-12.5 \mathrm{~Hz}$ and 0.4 , and the values for the latter were those used in the single-tensor calculations. Compared with the calculation with the single alignment tensor, the calculation with two-alignment tensors yields number of NOE and torsion angle violations in the upper loop region. This is because this region may be dynamic and nonstructured, and the interpretation of the RDCs is problematic. Therefore, the final ensemble of structures was calculated without RDCs from the upper loop region. The Pearson's correlation (Bax et al. 2001) between the normalized calculated and experimental values for the stem structure is 0.83 (Fig. 8B).

Chemical shift data for NRS23 RNA have been deposited in BioMagResBank (http://www.bmrb.wisc.edu), entry code 1534 . Coordinates for the NRS23 structures calculated with RDCs and DELPHIC database have been deposited in Protein Data Bank (http://www.rcsb.org), access code xxx.

\section{ACKNOWLEDGMENTS}

We acknowledge Dr. G. Marius Clore for discussion about the DELPHIC database, Dennis A. Torchia for use of a Bruker 500$\mathrm{MHz}$ spectrometer equipped with an HCP triple resonance probe, David E. Draper for use of a Cary 400 Bio spectrophotometer, R. Andrew Byrd and Christiane Branlant for encouragement, and Jason LeBlanc for review of the manuscript. This work was supported in part by National Institutes of Health (NIH) grant RO1CA48745 to K.L.B. K.E.G. was supported by NIH predoctoral training grant T32GM07231.

The publication costs of this article were defrayed in part by payment of page charges. This article must therefore be hereby marked "advertisement" in accordance with 18 USC section 1734 solely to indicate this fact.

Received January 7, 2004; accepted June 9, 2004.

\section{REFERENCES}

Arrigo, S. and Beemon, K. 1988. Regulation of Rous sarcoma virus RNA splicing and stability. Mol. Cell. Biol. 8: 4858-4867.

Batey, R.T., Inada, M., Kujawinski, E., Puglisi, J.D., and Williamson, J.R. 1992. Preparation of isotopically labeled ribonucleotides for multidimensional NMR spectroscopy of RNA. Nucleic Acids Res. 20: 4515-4523.

Bax, A., Kontaxis, G., and Tjandra, N. 2001. Dipolar couplings in macromolecular structure determination. Methods Enzymol. 339: $127-174$. 
Bindereif, A. and Green, M.R. 1987. An ordered pathway of snRNP binding during mammalian pre-mRNA splicing complex assembly. EMBO J. 6: 2415-2424.

Burge, C.B., Tuschl, T., and Sharp, P.A. 1999. Splicing of Precursors to mRNAs by the spliceosome. In The RNA world, 2nd ed. (eds. R.F. Gesteland et al.), pp. 525-560. Cold Spring Harbor Laboratory Press, Cold Spring Harbor, NY.

Cabello-Villegas, J., Winkler, M.E., and Nikonowicz, E.P. 2002. Solution conformations of unmodified and $\mathrm{A}(37) \mathrm{N}(6)$ - dimethylallyl modified anticodon stem-loops of Escherichia coli tRNA(Phe). J. Mol. Biol. 319: 1015-1034.

Caputi, M., Mayeda, A., Krainer, A.R., and Zahler, A.M. 1999. hnRNP $\mathrm{A} / \mathrm{B}$ proteins are required for inhibition of HIV-1 pre-mRNA splicing. EMBO J. 18: 4060-4067.

Clore, G.M. and Kuszewski, J. 2003. Improving the accuracy of NMR structures of RNA by means of conformational database potentials of mean force as assessed by complete dipolar coupling crossvalidation. J. Am. Chem. Soc. 125: 1518-1525.

Clore, G.M., Gronenborn, A.M., and Bax, A. 1998. A robust method for determining the magnitude of the fully asymmetric alignment tensor of oriented macromolecules in the absence of structural information. J. Magn. Reson. 133: 216-221.

Cook, C.R. and McNally, M.T. 1999. Interaction between the negative regulator of splicing element and a 3 ' splice site: Requirement for U1 small nuclear ribonucleoprotein and the $3^{\prime}$ splice site branch point/pyrimidine tract. J. Virol. 73: 2394-2400.

Davanloo, P., Rosenberg, A.H., Dunn, J.J., and Sturdier, F.W. 1984. Cloning and expression of the gene for bacteriophage T7 RNA polymerase. Proc. Natl. Acad. Sci. 81: 2035-2039.

Delaglio, F., Grzesiek, S., Vuister, G.W., Zhu, G., Pfeifer, J., and Bax, A. 1995. NMRPipe: A multidimensional spectral processing system based on UNIX pipes. J. Biomol. NMR 6: 277-293.

Dingley, A.J. and Grzesiek, S. 1998. Direct observation of hydrogen bonds in nucleic acid base pairs by internucleotide (2)J(NN) couplings. J. Am. Chem. Soc. 120: 8293-8297.

$\mathrm{Du}, \mathrm{H}$. and Rosbash, M. 2002. The U1 snRNP protein U1C recognizes the $5^{\prime}$ splice site in the absence of base pairing. Nature 419: 86-90.

Eperon, I.C., Ireland, D.C., Smith, R.A., Mayeda, A., and Krainer, A.R. 1993. Pathways for selection of $5^{\prime}$ splice sites by U1 snRNPs and SF2/ASF. EMBO J. 12: 3607-3617.

Fogel, B.L. and McNally, M.T. 2000. A cellular protein, hnRNP H, binds to the negative regulator of splicing element from Rous sarcoma virus. J. Biol. Chem. 275: 32371-32378.

Gontarek, R.R., McNally, M.T., and Beemon, K. 1993. Mutation of an RSV intronic element abolishes both U11/U12 snRNP binding and negative regulation of splicing. Genes \& Dev. 7: 1926-1936.

Hall, S.L. and Padgett, R.A. 1994. Conserved sequences in a class of rare eukaryotic nuclear introns with non-consensus splice sites. J. Mol. Biol. 239: 357-365.

Hansen, M.R., Hanson, P., and Pardi, A. 2000. Filamentous bacteriophage for aligning RNA, DNA, and proteins for measurement of nuclear magnetic resonance dipolar coupling interactions. Methods Enzymol. 317: 220-240.

Hastings, M.L., Wilson, C.M., and Munroe, S.H. 2001. A purine-rich intronic element enhances alternative splicing of thyroid hormone receptor mRNA. RNA 7: 859-874.

Hennig, M. and Williamson, J.R. 2000. Detection of N-H center dot center dot center dot $\mathrm{N}$ hydrogen bonding in RNA via scalar couplings in the absence of observable imino proton resonances. Nucleic Acids Res. 28: 1585-1593.

Hibbert, C.S., Gontarek, R.R., and Beemon, K.L. 1999. The role of overlapping U1 and U11 $5^{\prime}$ splice site sequences in a negative regulator of splicing. RNA 5: 333-343.

Honig, A., Auboeuf, D., Parker, M.M., O’Malley, B.W., and Berget, S.M. 2002. Regulation of alternative splicing by the ATP-dependent DEAD-box RNA helicase p72. Mol. Cell. Biol. 22: 5698-5707.

Hu, W., Bouaziz, S., Skripkin, E., and Kettani, A. 1999. Determination of ${ }^{3} \mathrm{~J}\left(\mathrm{H} 3^{\prime}{ }_{\mathrm{i}}, \mathrm{P}_{\mathrm{i}+1}\right)$ and ${ }^{3} \mathrm{~J}\left(\mathrm{H}^{\prime}{ }_{\mathrm{i}} / \mathrm{H} 5^{\prime \prime}{ }_{\mathrm{i}}, \mathrm{P}_{\mathrm{i}}\right)$ coupling constants in ${ }^{13} \mathrm{C}-$ labeled nucleic acids using constant-time HMQC. J. Magn. Reson.
139: 181-185.

Jacquenet, S., Ropers, D., Bilodeau, P.S., Damier, L., Mougin, A., Stoltzfus, C.M., and Branlant, C. 2001. Conserved stem-loop structures in the HIV-1 RNA region containing the A3 $3^{\prime}$ splice site and its cis-regulatory element: Possible involvement in RNA splicing. Nucleic Acids Res. 29: 464-478.

Johnson, B.A. and Blevins, R.A. 1994. NMR View-A computer program for the visualization and analysis of NMR data. J. Biomol. NMR 4: 603-614.

Jucker, F.M., Heus, H.A., Yip, P.F., Moors, E.H., and Pardi, A. 1996. A network of heterogeneous hydrogen bonds in GNRA tetraloops. J. Mol. Biol. 264: 968-980.

Kay, L., Keifer, P., Saarinen, T. 1992. Pure absorption gradient enhanced heteronuclear single quantum correlation spectroscopy with improved sensitivity. J. Am. Chem. Soc. 114: 10663-10665.

Kolossova, I. and Padgett, R.A. 1997. U11 snRNA interacts in vivo with the $5^{\prime}$ splice site of U12-dependent (AU-AC) pre-mRNA introns. RNA 3: 227-233.

Laing, L.G. and Draper, D.E. 1994. Thermodynamics of RNA folding in a highly conserved ribosomal RNA domain. J. Mol. Biol. 237: 560-576.

Legault, P., Jucker, F.M., and Pardi, A. 1995. Improved measurement of C-13, P-31 J-coupling-constants in isotopically labeled RNA. FEBS Lett. 362: 156-160.

Lukavsky, P.J. and Puglisi, J.D. 2001. RNAPack: An integrated NMR approach to RNA structure determination. Methods 25: 316-332.

Lund, M. and Kjems, J. 2002. Defining a 5' splice site by functional selection in the presence and absence of U1 snRNA $5^{\prime}$ end. RNA 8: 166-179.

Marino, J.P., Schwalbe, H., Anklin, C., Bermel, W., Crothers, D.M., and Griesinger, C. 1995. Sequential correlation of anomeric ribose protons and intervening phosphorus in RNA oligonucleotides by a H-1,C-13,P-31 triple-resonance experiment-HCP-CCH-TOCSY. J. Biomol. NMR 5: 87-92.

Marino, J.P., Diener, J.L., Moore, P.B., and Griesinger, C. 1997. Multiple-quantum coherence dramatically enhances the sensitivity of $\mathrm{CH}$ and $\mathrm{CH} 2$ correlations in uniformly 13C-labeled RNA. J. Am. Chem. Soc. 119: 7361-7366.

Marky, L.A. and Breslauer, K.J. 1987. Calculating thermodynamic data for transitions of any molecularity from equilibrium melting curves. Biopolymers 26: 1601-1620.

Mathews, D.H., Sabina, J., Zuker, M., and Turner, D.H. 1999. Expanded sequence dependence of thermodynamic parameters improves prediction of RNA secondary structure. J. Mol. Biol. 288: 911-940.

McCallum, S.A. and Pardi, A. 2003. Refined solution structure of the iron-responsive element RNA using residual dipolar couplings. J. Mol. Biol. 326: 1037-1050.

McNally, M.T. and Beemon, K. 1992. Intronic sequences and 3' splice sites control Rous sarcoma virus RNA splicing. J. Virol. 66: 6-11.

McNally, L.M. and McNally, M.T. 1998. An RNA splicing enhancerlike sequence is a component of a splicing inhibitor element from Rous sarcoma virus. Mol. Cell. Biol. 18: 3103-3111.

- 1999. U1 small nuclear ribonucleoprotein and splicing inhibition by the rous sarcoma virus negative regulator of splicing element. J. Virol. 73: 2385-2393.

McNally, M.T., Gontarek, R.R., and Beemon, K. 1991. Characterization of Rous sarcoma virus intronic sequences that negatively regulate splicing. Virology 185: 99-108.

Michaud, S. and Reed, R. 1991. An ATP-independent complex commits pre-mRNA to the mammalian spliceosome assembly pathway. Genes \& Dev. 5: 2534-2546.

Molinaro, M. and Tinoco, I. 1995. Use of ultra-stable UNCG tetraloop hairpins to fold RNA structures-Thermodynamic and spectroscopic applications. Nucleic Acids Res. 23: 3056-3063.

Mougin, A., Gottschalk, A., Fabrizio, P., Luhrmann, R., and Branlant, C. 2002. Directed probing of RNA structure and RNA-protein interactions in purified HeLa cells and yeast spliceosomal U4/ U6.U5 tri-snRNP particles. J. Mol. Biol. 317: 631-649. 
Mount, S.M., Pettersson, I., Hinterberger, M., Karmas, A., and Steitz, J.A. 1983. The U1 small nuclear RNA-protein complex selectively binds a 5' splice site in vitro. Cell 33: 509-518.

Mueller, L. 1979. Sensitivity enhanced detection of weak nuclei using heteronuclear multiple quantum coherence. J. Am. Chem. Soc. 101: 4481-4484.

Nikonowicz, E.P. and Pardi, A. 1993. An efficient procedure for assignment of the proton, carbon and nitrogen resonances in $13 \mathrm{C} /$ $15 \mathrm{~N}$ labeled nucleic acids. J. Mol. Biol. 232: 1141-1156.

Nikonowicz, E.P., Sirr, A., Legault, P., Jucker, F.M., Baer, L.M., and Pardi, A. 1992. Preparation of $13 \mathrm{C}$ and $15 \mathrm{~N}$ labelled RNAs for heteronuclear multi-dimensional NMR studies. Nucleic Acids Res. 20: 4507-4513.

O'Sullivan, C.T. 2001. "Defining the role of a splicing suppressor in the life cyle of an avian retrovirus." Ph.D. thesis, Johns Hopkins University, Baltimore, MD.

O’Sullivan, C.T., Polony, T.S., Paca, R.E., and Beemon, K.L. 2002. Rous sarcoma virus negative regulator of splicing selectively suppresses $s r c$ mRNA splicing and promotes polyadenylation. Virology 302: 405-412.

Paca, R.E., Hibbert, C.S., O’Sullivan, C.T., and Beemon, K.L. 2001. Retroviral splicing suppressor requires three nonconsensus uridines in a 5' splice site-like sequence. J. Virol. 75: 7763-7768.

Rabson, A.B. and Graves, B.J. 1997. Synthesis and processing of viral RNA. In Retroviruses (eds. J.M. Coffin et al.), pp. 205-261. Cold Spring Harbor Laboratory Press, Cold Spring Harbor, NY.

Rinkel, L.J. and Altona, C. 1987. Conformational analysis of the deoxyribofuranose ring in DNA by means of sums of proton-proton coupling constants-A graphical method. J. Biomol. Struct. Dyn. 4: 621-649.

Robberson, B.L., Cote, G.J., and Berget, S.M. 1990. Exon definition may facilitate splice site selection in RNAs with multiple exons.
Mol. Cell. Biol. 10: 84-94.

Roberts, T.M. and Boris-Lawrie, K. 2003. Primary sequence and secondary structure motifs in spleen necrosis virus RU5 confer translational utilization of unspliced human immunodeficiency virus type 1 reporter RNA. J. Virol. 77: 11973-11984.

Schwieters, C.D., Kuszewski, J.J., Tjandra, N., and Clore, G.M. 2003. The Xplor-NIH NMR molecular structure determination package. J. Magn. Reson. 160: 65-73.

Solnick, D. 1985. Alternative splicing caused by RNA secondary structure. Cell 43: 667-676.

Szyperski, T., Fernandez, C., Ono, A., Wuthrich, K., and Kainosho, M. 1999. The 2D $\{\mathrm{P}-31\}$ spin-echo-difference constant-time [C-13, H-1]- HMQC experiment for simultaneous determination of (3) J(H3' P) and (3) J(C4' P) in C-13-labeled nucleic acids and their protein complexes. J. Magn. Reson. 140: 491-494.

Vallurupalli, P. and Moore, P.B. 2002. Measurement of $\mathrm{H}_{2}{ }^{\prime}-\mathrm{C}^{\prime}$ ' and H3'-C3' dipolar couplings in RNA molecules. J. Biomol. NMR 24: 63-66.

Varani, G., Aboul-ela, F., and Allain, F.H.T. 1996. NMR investigation of RNA structure. Prog. Nucl. Mag. Res. Sp. 29: 51-127.

Walsh, J., Cabello-Villegas, J., and Wang., Y-X. 2004. Periodicity in dipolar coupling and nucleic acid structure. J. Am. Chem. Soc. 126: 1938-1939.

Weigelt, J. 1998. Single scan, sensitivity- and gradient-enhanced TROSY for multidimensional NMR experiments. J. Am. Chem. Soc. 120: 10778-10779.

Znosko, B.M., Silvestri, S.B., Volkman, H., Boswell, B., and Serra, M.J. 2002. Thermodynamic parameters for an expanded nearest-neighbor model for the formation of RNA duplexes with single nucleotide bulges. Biochemistry 41: 10406-10417.

Zuker, M. 2003. Mfold web server for nucleic acid folding and hybridization prediction. Nucleic Acids Res. 31: 3406-3415. 

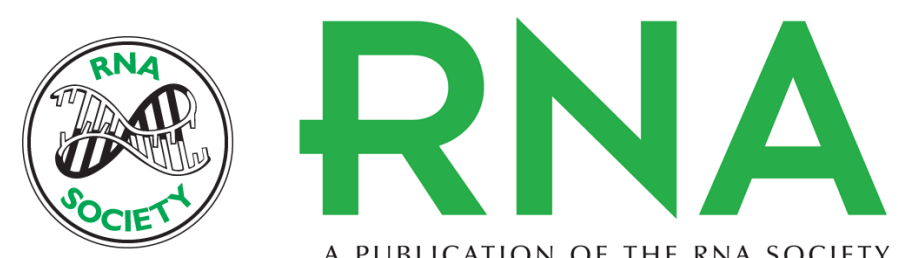

A PUBLICATION OF THE RNA SOCIETY

\section{Solution structure of the pseudo-5' splice site of a retroviral splicing suppressor}

JAVIER CABELLO-VILLEGAS, KEITH E. GILES, ANA MARIA SOTO, et al.

RNA 2004 10: 1388-1398

References This article cites 61 articles, 18 of which can be accessed free at: http://rnajournal.cshlp.org/content/10/9/1388.full.html\#ref-list-1

\section{License}

Email Alerting Receive free email alerts when new articles cite this article - sign up in the box at the Service top right corner of the article or click here.

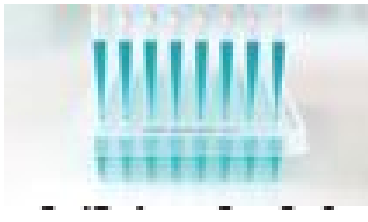

